\title{
Identifikasi miskonsepsi materi ikatan kovalen pada mahasiswa kimia tahun pertama universitas negeri malang menggunakan tes diagnostik two-tier
}

\author{
Wardatul Istiqomah, Sri Rahayu*, M. Muchson \\ Universitas Negeri Malang, Jl. Semarang No. 5 Malang, Jawa Timur, Indonesia \\ *Penulis korespondensi, Surel: sri.rahayu.fmipa@um.ac.id
}

Paper received: 01-06-2021; revised: 15-06-2021; accepted: 30-06-2021

\begin{abstract}
The concept of chemistry must be well understood because the concept of chemistry is hierarchical and sequential. In addition, the concept of chemistry is abstract, which can provoke misconceptions. This study aims to identify misconceptions about the covalent bonding material and to determine the percentage of misconceptions about these materials. The results showed that a misconception was observed in 10 concepts of covalent bonding material with the following percentages: 1) 23 percent of the concepts forming elements of covalent compounds, the covalent compounds must be composed of non-metallic elements with non-metallic elements; 2) 69 percent on the Lewis structure concept, the total number of electrons based on the Lewis structure drawing is the number of valence electrons; 3 ) 54 percent in the concept of double bonds, the breaking energy of the double bonds is twice that of the energy of the single bonds; 4$) 35$ percent on the concept of covalent coordination bonds, the covalent coordination bonds are shorter than the covalent bonds; 5) 54 percent on the concept of polar covalent bonds and molecular polarity, the pair of binding electrons is located at the same distance between two bonding atoms; 6 ) 27 percent in the concept of formal charge, the value of the influences of electronegativity in the determination of the formal charge; 7) on the notion of byte rule and the stability of covalent compounds, 27 percent of the stable Lewis structure does not have a free electron pair (PEB) and respects the byte rule; 62 percent chlorine gas will form the $\mathrm{Cl} 2$ molecule because it follows the octet rule; and 54 percent of the covalent bonds store chemical energy; 8) 42 percent on the concept of molecular form, the molecular form of a compound is determined by the repulsion of binding electron pairs; 9) on the concept of intermolecular forces and the properties of covalent compounds, 38 percent of the energy required to boil the table salt is superior because the table salt is an ionic bond; and 81 percent of the strongest interactions are hydrogen bonds; and 10) in the concept of valence bond theory, 23 percent of the most important particles in the formation of covalent bonds are valence electrons; and 27 percent electron sharing means sharing one (1) electron with two atoms, as in the case of sharing an apple for two people.
\end{abstract}

Keywords: Misconceptions; two-tier diagnostic instruments; covalent bonding

\begin{abstract}
Abstrak
Konsep ilmu kimia perlu dipahami dengan baik, karena konsep ilmu kimia berjenjang dan berurutan. Selain itu, konsep ilmu kimia bersifat abstrak, sehingga dapat menyebabkan miskonsepsi. Penelitian ini bertujuan untuk mengidentifikasi miskonsepsi pada materi ikatan kovalen dan mengetahui persentase miskonsepsi pada materi tersebut. Hasil penelitian menunjukkan bahwa miskonsepsi terjadi pada 10 konsep materi ikatan kovalen dengan persentase sebagai berikut: 1) 23 persen pada konsep unsur-unsur pembentuk senyawa kovalen, senyawa kovalen harus tersusun atas unsur non logam dengan unsur non logam;2) 69 persen pada konsep struktur Lewis, elektron total berdasarkan gambar struktur Lewis adalah jumlah elektron valensi; 3) 54 persen pada konsep ikatan rangkap, energi pemutusan ikatan rangkap dua kali lipat daripada energi pemutusan ikatan tunggal; 4) 35 persen pada konsep ikatan kovalen koordinasi, ikatan kovalen koordinasi lebih pendek daripada ikatan kovalen; 5) 54 persen pada konsep ikatan kovalen polar dan kepolaran molekul, pasangan elektron ikatan terletak pada jarak yang sama diantara dua atom yang berikatan; 6) 27 persen pada konsep muatan formal, nilai elektronegativitas berpengaruh dalam menentukan muatan formal; 7) pada konsep aturan oktet dan kestabilan
\end{abstract}


senyawa kovalen, 27 persen struktur Lewis yang stabil tidak memiliki Pasangan Elektron Bebas (PEB) dan memenuhi aturan oktet; 62 persen gas klorin akan membentuk molekul $\mathrm{Cl} 2$ karena memenuhi aturan oktet; dan 54 persen ikatan kovalen menyimpan energi kimia; 8) 42 persen pada konsep bentuk molekul, bentuk molekul suatu senyawa ditentukan tolakan pasangan elektron ikatan; 9) pada konsep gaya antar molekul dan sifat-sifat senyawa kovalen, 38 persen energi yang dibutuhkan untuk mendidihkan garam dapur lebih besar karena garam dapur merupakan ikatan ionik; dan 81 persen interaksi tarik-menarik yang paling kuat adalah ikatan hidrogen; dan 10) pada konsep teori ikatan valensi, 23 persen partikel paling penting dalam pembentukan ikatan kovalen adalah elektron valensi; dan 27 persen sharing electron berarti pemakaian bersama 1 (satu) elektron oleh dua atom, seperti pada kasus berbagi sebuah apel untuk dua orang.

Kata kunci: miskonsepsi; instrumen diagnostik two-tier; ikatan kovalen

\section{Pendahuluan}

Pengajaran ilmu kimia dimulai dari konsep-konsep yang sederhana, kemudian dari konsep yang sederhana tersebut dibangun konsep-konsep yang lebih kompleks. Oleh karena itu, kajian dalam ilmu kimia dimulai dari kajian tentang konsep (Effendy, 2002). Menurut Gusbandono (2013) banyak siswa memaknai konsep kimia sebagai konsep yang membingungkan. Hal ini karena konsep ilmu kimia bersifat abstrak yaitu susah untuk dialami secara langsung dan nyata (Effendy, 2002). Selain itu konsep ilmu kimia tersusun secara berurutan dan berjenjang (Kean \& Middlecamp, 1985). Berdasarkan sifat konsep ilmu kimia yang berurutan dan berjenjang menunjukkan bahwa konsep ilmu kimia perlu dipahami dengan baik, karena apabila mahasiswa mengalami kesulitan pada salah satu konsep dasar, maka mahasiswa tersebut kemungkinan akan mengalami kesulitas pada konsep yang lebih kompleks. Karakteristik konsep ilmu kimia tersebut menjadi salah satu penyebab yang memperbesar kemungkinan terjadinya miskonsepsi (Effendy, 2002). Miskonsepi menurut Sendur, et al (2010) merupakan prekonsepsi (konsepsi awal) yang bertentangan dengan sudut pandang ilmiah. Selain itu, miskonsepsi merupakan kesalahan yang terjadi secara konsisten (Borg dalam Effendy, 2002). Miskonsepsi yang ada dalam diri siswa susah untuk dihilangkan (Hamzah, 2008). Hasil penelitian yang dilakukan oleh Sunyono, dkk (2009) menyatakan bahwa topik ikatan kimia merupakan materi yang sulit dipelajari siswa. Salah satu materi yang terdapat pada ikatan kimia adalah materi ikatan kovalen dan merupakan materi yang mengalami banyak miskonsepsi (Al-Balushi, M. S., et al, 2012). Beberapa peneliti telah melakukan penelitian miskonsepsi pada topik ikatan kovalen diantaranya yaitu AlBalushi, M. S., et al (2012), Dhindsa, et al (2009), dan Tan \& Treagust (1999). Miskonsepsi dapat disebabkan oleh tiga hal yaitu pengetahuan awal siswa, karakteristik materi yang dipelajari, dan kegiatan pembelajaran (Nakiboglu, 2003). Dalam sebuah penelitian yang dilakukan oleh Nahum (2004) disebutkan bahwa guru menjadi salah satu sumber miskonsepsi yaitu melalui kegiatan pembelajaran yang diberikan. Mahasiswa merupakan calon guru yang nantinya akan mengajarkan materi yang diperoleh selama mengikuti kegiatan perkuliahan. Apabila mahasiswa mengalami miskonsepsi terhadap suatu materi, mahasiswa tersebut juga akan menyebabkan anak didiknya mengalami miskonsepsi yang serupa. Miskonsepsi dapat terjadi pada mahasiswa karena pada dasarnya setiap mahasiswa sudah membawa konsep awal tentang kimia sebelum mengikuti proses pembelajaran di kampus dan terkadang konsep awal tersebut tidak sesuai dengan konsep yang sebenarnya.

Instrumen diagnostik two-tier merupakan salah satu instrumen yang dapat digunakan untuk mendeteksi miskonsepsi. Hal ini karena instrumen terdiri dari dua bagian yaitu tier pertama terdiri dari pilihan jawaban dan tier kedua terdiri dari pilihan alasan yang mengacu pada tier pertama. Berdasarkan hal tersebut peneliti tertarik untuk mengidentifikasi 
miskonsepsi materi ikatan kovalen pada Mahasiswa Kimia Kimia Tahun Pertama Universitas Negeri Malang.

\section{Metode}

Metode penelitian ini digunakan adalah penelitian deskriptif. Subjek pengambilan data dalam penelitian ini adalah 26 mahasiswa kimia tahun pertama Universitas Negeri Malang yang sedang menempuh matakuliah Kimia Dasar Semester Antara. Instrumen yang digunakan pada penelitian ini berupa tes diagnostik two tier yang terdiri dari 40 soal. Pada instrumen ini terdapat 10 konsep yang diukur yaitu (1) unsur-unsur pembentuk senyawa kovalen, (2) struktur Lewis, (3) ikatan rangkap, (4) ikatan kovalen koordinasi, (5) ikatan kovalen polar dan kepolaran molekul, (6) muatan formal, (7) aturan oktet dan kestabilan senyawa kovalen, (8) bentuk molekul, (9) gaya antar molekul dan sifat-sifat senyawa kovalen, dan (10) teori ikatan valensi.. Setiap konsep yang terdapat pada instrumen ini di tes dengan dua soal yang berbeda. Tes diagnostik two tier yang digunakan adalah soal tes yang dikembangkan oleh peneliti Layly (2016).

Langkah pada penelitian ini ada dua yaitu pengumpulan data dan analisis data. Pada tahap pengumpulan data, data diperoleh dari sumber yaitu tes tulis dan wawancara. Langkah yang kedua yaitu analisis data penelitian. Pada langkah ini dilakukan tiga tahap, tahap yang pertama yaitu dilakukan koreksi dan pengkategorian jawaban, tahap yang kedua yaitu perhitungan persentase pilihan jawaban dan persentase miskonsepsi dan tahap yang terakhir yaitu tindak lanjut hasil perhitungan persentase dengan wawancara.

\section{Hasil dan Pembahasan}

Pada penelitian ini ditemukan miskonsepsi pada 10 konsep pada materi ikatan kovalen.

\subsection{Miskonsepsi pada Konsep Unsur-Unsur Pembentuk Senyawa Kovalen}

Persentase mahasiswa yang mengalami miskonsepsi pada konsep unsur-unsur pembentuk senyawa kovalen dapat diidentifikasi melalui pasangan soal nomor 37 \& 40. Hasil identifikasi dapat dilihat pada Tabel 1.

Tabel 1 Persentase Miskonsepsi pada Konsep Unsur-Unsur Pembentuk Senyawa Kovalen

\begin{tabular}{lllll}
\hline Miskonsepsi & $\begin{array}{l}\text { Nomor } \\
\text { Soal }\end{array}$ & $\begin{array}{l}\text { Pilihan } \\
\text { Jawaban }\end{array}$ & $\begin{array}{l}\text { Persentase Pilihan } \\
\text { Jawaban } \\
\text { Miskonsepsi }\end{array}$ & $\begin{array}{l}\text { Persentase } \\
\text { Miskonsepsi } \\
\text { Total }\end{array}$ \\
\hline $\begin{array}{l}\text { Senyawa } \\
\text { kovalen harus } \\
\text { tersusun atas }\end{array}$ & 37 & $2 \mathrm{~A}$ & $12 \%$ & \\
$\begin{array}{l}\text { unsur non } \\
\text { logam dengan } \\
\text { unsur non }\end{array}$ & 40 & $2 \mathrm{~A}$ & $15 \%$ & $23 \%$ \\
logam & & & & \\
\hline
\end{tabular}

Pada konsep ini ditemukan miskonsepsi yang terjadi sebesar 23\%. Mahasiswa menganggap bahwa senyawa kovalen harus tersusun atas unsur non logam dengan unsur non logam. Berdasarkan hasil wawancara dapat diketahui bahwa siswa menggolongkan ikatan kimia menjadi ikatan kovalen dan ikatan ionik. Temuan ini 
sejalan dengan penelitian Uce (2015) yang menyatakan bahwa siswa menganggap ikatan kovalen terbentuk dari transfer elektron antara dua unsur non logam.

\subsection{Miskonsepsi pada Konsep Struktur Lewis}

Persentase mahasiswa yang mengalami miskonsepsi pada konsep struktur Lewis dapat diidentifikasi melalui pasangan soal nomor 38 \& 39. Hasil identifikasi dapat dilihat pada Tabel 2 .

Tabel 2 Persentase Miskonsepsi pada Konsep Struktur Lewis

\begin{tabular}{lllll}
\hline Miskonsepsi & $\begin{array}{l}\text { Nomor } \\
\text { Soal }\end{array}$ & $\begin{array}{l}\text { Pilihan } \\
\text { Jawaban }\end{array}$ & $\begin{array}{l}\text { Persentase Pilihan } \\
\text { Jawaban } \\
\text { Miskonsepsi }\end{array}$ & $\begin{array}{l}\text { Persentase } \\
\text { Miskonsepsi } \\
\text { Total }\end{array}$ \\
\hline $\begin{array}{l}\text { Elektron total } \\
\text { berdasakan } \\
\text { gambar struktur }\end{array}$ & 38 & $2 \mathrm{C}$ & $35 \%$ & \\
$\begin{array}{l}\text { Lewis adalah } \\
\text { jumlah elektron } \\
\text { valensi }\end{array}$ & 39 & 2C & $27 \%$ & $69 \%$ \\
\hline
\end{tabular}

Pada konsep ini ditemukan miskonsepsi yang terjadi sebesar 69\%. Mahasiswa menyatakan bahwa elektron total berdasarkan gambar pada struktur Lewis adalah jumlah dari elektron valensi. Berdasarkan hasil wawancara dapat diketahui bahwa mahasiswa belum bisa membedakan elektron valensi dengan elektron total yang dimiliki atom. Hal ini dapat disebabkan pada pembelajaran mengenai struktur Lewis, mahasiswa seringkali tidak selalu menggunakan kata "valensi" ketika menyebutkan jumlah elektron valensi yang dimiliki oleh atom. Temuan ini sejalan dengan penelitian yang dilakukan oleh Luxford \& Bretz (2014) yang menyatakan bahwa titik dalam struktur Lewis merupakan semua elektron dalam senyawa.

\subsection{Miskonsepsi pada Konsep Ikatan Rangkap}

Persentase mahasiswa yang mengalami miskonsepsi pada konsep ikatan rangkap dapat diidentifikasi melalui pasangan soal nomor $5 \& 30$. Hasil identifikasi dapat dilihat pada Tabel 3.

Tabel 3 Persentase Miskonsepsi pada Konsep Ikatan Rangkap

\begin{tabular}{lllll}
\hline Miskonsepsi & $\begin{array}{c}\text { Nomor } \\
\text { Soal }\end{array}$ & $\begin{array}{l}\text { Pilihan } \\
\text { Jawaban }\end{array}$ & $\begin{array}{l}\text { Persentase Pilihan } \\
\text { Jawaban } \\
\text { Miskonsepsi }\end{array}$ & $\begin{array}{l}\text { Persentase } \\
\text { Miskonsepsi } \\
\text { Total }\end{array}$ \\
\hline $\begin{array}{l}\text { Energi pemutusan } \\
\text { ikatan rangkap dua }\end{array}$ & 5 & 2B & $42 \%$ & \\
$\begin{array}{l}\text { kali lebih besar } \\
\text { daripada energi }\end{array}$ & & & & $54 \%$ \\
$\begin{array}{l}\text { pemutusan ikatan } \\
\text { tunggal karena pada } \\
\text { ikatan rangkap dua } \\
\text { ada dua ikatan }\end{array}$ & 30 & 2B & $38 \%$ & \\
\hline
\end{tabular}

Pada konsep ini ditemukan miskonsepsi yang terjadi sebesar 54\%. Mahasiswa menganggap bahwa energi pemutusan ikatan rangkap dua kali lipat daripada energi 
pemutusan ikatan tunggal karena pada ikatan tunggal hanya ada satu ikatan, sedangkan pada ikatan rangkap dua ada dua ikatan sehingga pemutusan ikatan rangkap dua pasti membutuhkan energi dua kali lipat. Temuan ini sejalan dengan penelitian yang dilakukan oleh Luxford \& Bretz (2014) ditemukan miskonsepsi sejenis dengan ini pada siswa di Amerika Serikat yaitu menganggap ikatan sama dengan garis.

\subsection{Miskonsepsi pada Konsep Ikatan Kovalen Koordinasi}

Persentase mahasiswa yang mengalami miskonsepsi pada konsep ikatan kovalen koordinasi dapat diidentifikasi melalui pasangan soal nomor 4 \& 34 . Hasil identifikasi dapat dilihat pada Tabel 4 .

Tabel 4 Persentase Miskonsepsi pada Konsep Ikatan Kovalen Koordinasi

\begin{tabular}{lllll}
\hline Miskonsepsi & $\begin{array}{l}\text { Nomor } \\
\text { Soal }\end{array}$ & $\begin{array}{l}\text { Pilihan } \\
\text { Jawaban }\end{array}$ & $\begin{array}{l}\text { Persentase } \\
\text { Pilihan } \\
\text { Jawaban } \\
\text { Miskonsepsi }\end{array}$ & $\begin{array}{l}\text { Persentase } \\
\text { Miskonsepsi } \\
\text { Total }\end{array}$ \\
\hline $\begin{array}{l}\text { Ikatan kovalen } \\
\text { koordinasi lebih } \\
\text { pendek daripada } \\
\text { ikatan kovalen }\end{array}$ & 4 & 1D & $27 \%$ & \\
$\begin{array}{l}\text { karena ikatan } \\
\text { kovalen koordinasi }\end{array}$ & & & & $35 \%$ \\
$\begin{array}{l}\text { lebih kuat daripada } \\
\text { ikatan kovalen }\end{array}$ & 34 & 1D & $19 \%$ & \\
\hline
\end{tabular}

Pada konsep ini ditemukan miskonsepsi yang terjadi sebesar 35\%. Mahasiswa menyatakan bahwa ikatan kovalen koordinasi lebih pendek daripada ikatan kovalen. Temuan ini sejalan dengan penelitian yang dilakukan oleh Layly (2016) yang menyatakan bahwa siswa mengalami miskonsepsi pada konsep ikatan koordinasi. Padahal, Menurut Jespenser et. al. (2012) setelah ikatan terbentuk, ikatan kovalen koordinasi benar-benar sama dengan ikatan kovalen lainnya.

\subsection{Miskonsepsi pada Konsep Ikatan Kovalen Polar dan Kepolaran Molekul}

Persentase mahasiswa yang mengalami miskonsepsi pada konsep ikatan kovalen polar dan kepolaran molekul dapat diidentifikasi melalui pasangan soal nomor 3 \& 31. Hasil identifikasi dapat dilihat pada Tabel 5. 
Tabel 5 Persentase Miskonsepsi pada Konsep Ikatan Kovalen Polar dan Kepolaran Molekul

\begin{tabular}{lllll}
\hline Miskonsepsi & $\begin{array}{l}\text { Nomor } \\
\text { Soal }\end{array}$ & $\begin{array}{l}\text { Pilihan } \\
\text { Jawaban }\end{array}$ & $\begin{array}{l}\text { Persentase Pilihan } \\
\text { Jawaban } \\
\text { Miskonsepsi }\end{array}$ & $\begin{array}{l}\text { Persentase } \\
\text { Miskonsepsi Total }\end{array}$ \\
\hline $\begin{array}{l}\text { Pasangan } \\
\text { elektron ikatan } \\
\text { terletak pada } \\
\text { jarak yang }\end{array}$ & 3 & $2 \mathrm{C}$ & $54 \%$ & \\
$\begin{array}{l}\text { sama diantara } \\
\text { dua atom yang } \\
\text { berikatan }\end{array}$ & 31 & 2C & $58 \%$ & $54 \%$ \\
\hline
\end{tabular}

Pada konsep ini ditemukan miskonsepsi yang terjadi sebesar 54\%. Mahasiswa menganggap bahwa pasangan elektron ikatan terletak pada jarak yang sama diantara dua atom yang berikatan. Berdasarkan hasil wawancara dapat diketahui bahwa mahasiswa menganggap pasangan elektron ikatan selalu berada pada jarak yang sama antara atom-atom yang berikatan. Hal ini dimungkinkan terjadi karena mahasiswa belum mengerti tentang keelektronegatifan pada atom. Temuan ini sejalan dengan penelitian yang dilakukan oleh Al-Balushi, M. S., et al. (2012) yang menemukan miskonsepsi ada gaya tarik menarik yang sama kuat dari pemberian elektron dalam atom yang berikatan kovalen.

\subsection{Miskonsepsi pada Konsep Muatan Formal}

Persentase mahasiswa yang mengalami miskonsepsi pada konsep muatan formal dapat diidentifikasi melalui pasangan soal nomor 8 \& 27. Hasil identifikasi dapat dilihat pada Tabel 6 .

Tabel 6 Persentase Miskonsepsi pada Konsep Muatan Formal

\begin{tabular}{lllll}
\hline Miskonsepsi & $\begin{array}{l}\text { Nomor } \\
\text { Soal }\end{array}$ & $\begin{array}{l}\text { Pilihan } \\
\text { Jawaban }\end{array}$ & $\begin{array}{l}\text { Persentase } \\
\text { Pilihan } \\
\text { Jawaban } \\
\text { Miskonsepsi }\end{array}$ & $\begin{array}{l}\text { Persentase } \\
\text { Miskonsepsi } \\
\text { Total }\end{array}$ \\
\hline $\begin{array}{l}\text { Nilai } \\
\text { elektronegativitas } \\
\text { berpengaruh }\end{array}$ & 8 & $2 \mathrm{~A}$ & $31 \%$ & $27 \%$ \\
$\begin{array}{l}\text { dalam } \\
\text { menentukan } \\
\text { muatan formal }\end{array}$ & 27 & $2 \mathrm{~A}$ & $23 \%$ & \\
\hline
\end{tabular}

Pada konsep ini ditemukan miskonsepsi yang terjadi sebesar 27\%. Mahasiswa menganggap bahwa nilai elektronegativitas atom berpengaruh dalam menentukan muatan formal. Hal ini dapat disebabkan karena mahasiswa tersebut belum memahami cara menentukan muatan formal dari suatu senyawa. Padahal, untuk menentukan muatan formal suatu senyawa menurut Effendy (2016) dihitung dengan cara elektron valensi dikurangi jumlah pasangan elektron bebas dikurangi setengah jumlah pasangan elektron ikatan $\left(Q_{F}=E V-N_{P E B}-1 / 2 N_{P E I}\right)$. 


\subsection{Miskonsepsi pada Konsep Aturan Oktet dan Kestabilan Senyawa Kovalen}

Persentase mahasiswa yang mengalami miskonsepsi pada konsep aturan oktet dan kestabilan senyawa kovalen dapat diidentifikasi melalui pasangan soal nomor 9 \& 26, 17 \& 28, dan 7 \& 18. Hasil identifikasi dapat dilihat pada Tabel 7.

Tabel 7 Persentase Miskonsepsi pada Konsep Aturan Oktet dan Kestabilan Senyawa Kovalen

\begin{tabular}{lllll}
\hline Miskonsepsi & $\begin{array}{l}\text { Nomor } \\
\text { Soal }\end{array}$ & $\begin{array}{l}\text { Pilihan } \\
\text { Jawaban }\end{array}$ & $\begin{array}{l}\text { Persentase Pilihan } \\
\text { Jawaban } \\
\text { Miskonsepsi }\end{array}$ & $\begin{array}{l}\text { Persentase } \\
\text { Miskonsepsi } \\
\text { Total }\end{array}$ \\
\hline $\begin{array}{l}\text { Struktur Lewis } \\
\text { stabil jika tidak } \\
\text { memiliki }\end{array}$ & 9 & $1 \mathrm{C}$ & $15 \%$ & \\
$\begin{array}{l}\text { Pasangan } \\
\begin{array}{l}\text { Elektron Bebas } \\
\text { (PEB) dan }\end{array}\end{array}$ & & & & $27 \%$ \\
$\begin{array}{l}\text { memenuhi } \\
\text { aturan oktet }\end{array}$ & 26 & $1 \mathrm{C}$ & $8 \%$ & \\
\hline $\begin{array}{l}\text { Gas klorin akan } \\
\text { membentuk } \\
\text { molekul Cl }\end{array}$ & 17 & $2 \mathrm{~A}$ & $50 \%$ & $62 \%$ \\
$\begin{array}{l}\text { karena } \\
\text { memenuhi } \\
\text { aturan oktet }\end{array}$ & 28 & 2A & $50 \%$ & $54 \%$ \\
\hline $\begin{array}{l}\text { Ikatan kovalen } \\
\text { menyimpan } \\
\text { energi kimia }\end{array}$ & 7 & $1 \mathrm{~A}$ & $50 \%$ & \\
\hline
\end{tabular}

Pada konsep ini ditemukan beberapa miskonsepsi yang pertama miskonsepsi sebesar 27\%. Mahasiswa menyatakan bahwa struktur Lewis yang stabil tidak memiliki Pasangan Elektron Bebas (PEB) dan memenuhi aturan oktet. Miskonsepsi yang kedua yaitu sebesar 62\%. Mahasiswa menganggap bahwa atom $\mathrm{Cl}$ harus berikatan dengan atom $\mathrm{Cl}$ yang lain untuk memenuhi aturan oktet. Miskonsepsi terakhir yaitu sebesar 54\%. Mahasiswa menganggap bahwa ikatan kovalen menyimpan energi karena pemutusan ikatan kovalen membebaskan energi dan pembentukan ikatan kovalen membutuhkan energi. Temuan miskonsepsi ini sejalan dengan penelitian yang dilakukan oleh Layly (2016) yang menyatakan bahwa siswa mengalami miskonsepsi pada konsep aturan oktet dan kestabilan senyawa kovalen.

\subsection{Miskonsepsi pada Konsep Bentuk Molekul}

Persentase mahasiswa yang mengalami miskonsepsi pada konsep bentuk molekul dapat diidentifikasi melalui pasangan soal $10 \& 25$. Hasil identifikasi dapat dilihat pada Tabel 8. 
Tabel 8 Persentase Miskonsepsi pada Konsep Bentuk Molekul

\begin{tabular}{lclll}
\hline Miskonsepsi & $\begin{array}{l}\text { Nomor } \\
\text { Soal }\end{array}$ & $\begin{array}{l}\text { Pilihan } \\
\text { Jawaban }\end{array}$ & $\begin{array}{l}\text { Persentase Pilihan } \\
\text { Jawaban } \\
\text { Miskonsepsi }\end{array}$ & $\begin{array}{l}\text { Persentase } \\
\text { Miskonsepsi } \\
\text { Total }\end{array}$ \\
\hline $\begin{array}{l}\text { Bentuk molekul } \\
\text { suatu senyawa } \\
\text { ditentukan tolakan } \\
\text { pasangan elektron } \\
\text { ikatan }\end{array}$ & 10 & 2D & $27 \%$ & \\
& 25 & 2D & $19 \%$ & $42 \%$ \\
\hline
\end{tabular}

Pada konsep ini ditemukan miskonsepsi sebesar 42\%. Mahasiswa menganggap bahwa bentuk molekul OCl2 adalah linear karena adanya tolakan dari pasangan elektron ikatan. Hal ini bisa terjadi karena mahasiswa belum memahami faktor yang mempengaruhi bentuk molekul dengan baik. Temuan ini sejalan dengan penelitian yang dilakukan oleh Setiawan (2017) yang menyatakan bahwa siswa mengalami miskonsepsi pada konsep bentuk molekul.

\subsection{Miskonsepsi pada Konsep Gaya Antar Molekul dan Sifat-Sifat Senyawa Kovalen}

Persentase mahasiswa yang mengalami miskonsepsi pada konsep gaya antar molekul dan sifat-sifat senyawa kovalen dapat diidentifikasi melalui pasangan soal 15 \& 20, dan 16\& 19. Hasil identifikasi dapat dilihat pada Tabel 9.

Tabel 9 Persentase Miskonsepsi pada Konsep Gaya Antar Molekul dan Sifat-Sifat Senyawa Kovalen

\begin{tabular}{lllll}
\hline Miskonsepsi & $\begin{array}{l}\text { Nomor } \\
\text { Soal }\end{array}$ & $\begin{array}{l}\text { Pilihan } \\
\text { Jawaban }\end{array}$ & $\begin{array}{l}\text { Persentase } \\
\text { Pilihan } \\
\text { Jawaban } \\
\text { Miskonsepsi }\end{array}$ & $\begin{array}{l}\text { Persentase } \\
\text { Miskonsepsi } \\
\text { Total }\end{array}$ \\
\hline $\begin{array}{l}\text { Dibutuhkan energi } \\
\text { yang lebih besar } \\
\text { untuk }\end{array}$ & 15 & $1 \mathrm{~A}$ & $31 \%$ & \\
$\begin{array}{l}\text { mendidihkan } \\
\text { garam dapur, } \\
\text { karena garam } \\
\text { dapur merupakan } \\
\text { ikatan ionik }\end{array}$ & 20 & $1 \mathrm{~A}$ & $46 \%$ & $38 \%$ \\
\hline $\begin{array}{l}\text { Interaksi tarik- } \\
\text { menarik yang } \\
\text { paling kuat adalah }\end{array}$ & 16 & 3C & $85 \%$ & \\
ikatan hidrogen & 19 & 3C & $73 \%$ & $81 \%$ \\
\hline
\end{tabular}

Pada konsep ini ditemukan beberapa miskonsepsi, yang pertama yaitu sebesar 38\%. Mahasiswa menganggap bahwa energi yang dibutuhkan untuk mendidihkan garam dapur lebih besar dibandingkan energi untuk mendidihkan minyak goreng, hal ini karena ikatan ionik lebih kuat dari ikatan kovalen yang mana garam dapur merupakan ikatan ionik dan minyak goreng merupakan ikatan kovalen. Temuan 
miskonsepsi ini sejalan dengan Tan \& Treagust (1999) yang menyatakan bahwa kekuatan gaya antar molekul ditentukan oleh kekuatan ikatan kovalen yang ada dalam molekul. Miskonsepsi yang kedua yaitu sebesar 81\%. Mahasiswa menganggap bahwa interaksi tarik-menarik yang paling kuat adalah ikatan hidrogen. Temuan ini sejalan dengan penelitian yang dilakukan oleh Layly (2016) yang menyatakan siswa mengalami miskonsepsi pada konsep gaya antar molekul.

\subsection{Miskonsepsi pada Konsep Teori Ikatan Valensi}

Persentase mahasiswa yang mengalami miskonsepsi pada konsep teori ikatan valensi dapat diidentifikasi melalui pasangan soal $13 \& 22$, dan $14 \& 21$. Hasil identifikasi dapat dilihat pada Tabel 10.

Tabel 10 Persentase Miskonsepsi pada Konsep Teori Ikatan Valensi

\begin{tabular}{lllll}
\hline Miskonsepsi & $\begin{array}{l}\text { Nomor } \\
\text { Soal }\end{array}$ & $\begin{array}{l}\text { Pilihan } \\
\text { Jawaban }\end{array}$ & $\begin{array}{l}\text { Persentase Pilihan } \\
\text { Jawaban } \\
\text { Miskonsepsi }\end{array}$ & $\begin{array}{l}\text { Persentase } \\
\text { Miskonsepsi } \\
\text { Total }\end{array}$ \\
\hline $\begin{array}{l}\text { Partikel paling } \\
\text { penting dalam } \\
\text { pembentukan ikatan }\end{array}$ & 13 & $1 \mathrm{~A}$ & $50 \%$ & \\
$\begin{array}{l}\text { kovalen adalah } \\
\text { elekton valensi }\end{array}$ & 22 & $1 \mathrm{~A}$ & $23 \%$ & $23 \%$ \\
\hline $\begin{array}{l}\text { Sharing electron } \\
\text { berarti pemakaian } \\
\text { bersama 1 (satu) } \\
\text { elektron oleh dua } \\
\text { atom, seperti pada } \\
\text { kasus berbagi } \\
\text { sebuah apel untuk } \\
\text { dua orang }\end{array}$ & 14 & $1 \mathrm{~A}$ & $27 \%$ & \\
& & & & \\
& & & & \\
\hline
\end{tabular}

Pada konsep ini ditemukan beberapa miskonsepsi, yang pertama yaitu sebesar 23\%. Mahasiswa menganggap bahwa partikel paling penting dalam pembentukan ikatan kovalen adalah elektron valensi. Miskonsepsi ini mirip dengan temuan dari Wang (2007) yang menyatakan ikatan kovalen terjadi karena adanya gaya tarikmenarik antara inti atom satu dengan inti atom yang lain. Miskonsepsi yang kedua yaitu sebesar $27 \%$. Mahasiswa percaya bahwa sharing electron berarti pemakaian bersama 1 (satu) elektron oleh dua atom, seperti kasus berbagi sebuah apel untuk dua orang. Miskonsepsi ini sejalan dengan temuan Tan, et al. di Singapura yang menyatakan bahwa sharing electron berarti pemakaian bersama satu elektron oleh dua atom, karena jika kedua atom bersama-sama menyumbangkan satu elektron tidak ada yang disebut berbagi, seperti pada kasus berbagi sebuah apel untuk dua orang. 


\section{Simpulan}

Berdasarkan hasil penelitian, disimpulkan bahwa ditemukan miskonsepsi pada 10 konsep materi ikatan kovalen yaitu sebagai berikut: 1) 23\% pada konsep unsur-unsur pembentuk senyawa kovalen, senyawa kovalen harus tersusun atas unsur non logam dengan unsur non logam; 2) 69\% pada konsep struktur Lewis, elektron total berdasarkan gambar struktur Lewis adalah jumlah elektron valensi; 3) 54\% pada konsep ikatan rangkap, energi pemutusan ikatan rangkap dua kali lipat daripada energi pemutusan ikatan tunggal; 4) 35\% pada konsep ikatan kovalen koordinasi, ikatan kovalen koordinasi lebih pendek daripada ikatan kovalen; 5) 54\% pada konsep ikatan kovalen polar dan kepolaran molekul, pasangan elektron ikatan terletak pada jarak yang sama diantara dua atom yang berikatan; 6) $27 \%$ pada konsep muatan formal, nilai elektronegativitas berpengaruh dalam menentukan muatan formal; 7) pada konsep aturan oktet dan kestabilan senyawa kovalen, $27 \%$ struktur Lewis yang stabil tidak memiliki Pasangan Elektron Bebas (PEB) dan memenuhi aturan oktet; 62\% gas klorin akan membentuk molekul $\mathrm{Cl}_{2}$ karena memenuhi aturan oktet; dan 54\% ikatan kovalen menyimpan energi kimia; 8) 42\% pada konsep bentuk molekul, bentuk molekul suatu senyawa ditentukan tolakan pasangan elektron ikatan; 9) pada konsep gaya antar molekul dan sifat-sifat senyawa kovalen, 38\% energi yang dibutuhkan untuk mendidihkan garam dapur lebih besar karena garam dapur merupakan ikatan ionik; dan 81\% interaksi tarik-menarik yang paling kuat adalah ikatan hidrogen; dan 10) pada konsep teori ikatan valensi, 23\% partikel paling penting dalam pembentukan ikatan kovalen adalah elektron valensi; dan $27 \%$ sharing electron berarti pemakaian bersama 1 (satu) elektron oleh dua atom, seperti pada kasus berbagi sebuah apel untuk dua orang.

\section{Daftar Rujukan}

Al-Balushi, S. M., Ambusaidi, A. K., Al-Shuaili, A. H., \& Taylor, N. (2012). Omani twelfth grade students' most common misconceptions in chemistry. Science Education International, 23(3), 221-240.

Dhinsda, H., \& Treagust, D. (2009). Conceptual understanding of bruneian tertiary students: chemical bonding and structure. Brunei international journal of science and mathematics education, 1(1), 33-51.

Effendy, E. (2009). Upaya untuk mengatasi kesalahan konsep dalam pengajaran kimia dengan menggunakan strategi konflik kognitif. Media komunikasi kimia, 6(2).

Effendy. (2016). Ilmu kimia: untuk siswa SMA dan MA kelas X.

Gusbandono, T., Sukardjo, J. S., \& Utomo, S. B. (2013). Pengaruh metode pembelajaran kooperatif student team achievement division (STAD) dilengkapi media animasi macromedia flash dan plastisin terhadap prestasi belajar siswa pada pokok bahasan ikatan kimia kelas X semester 1 SMA Negeri 1 Sambungmacan. Jurnal pendidikan kimia universitas sebelas maret, 2(4), 102-109.

Hamza, K. M., \& Wickman, P. O. (2009). Beyond explanations: What else do students need to understand science?. Science Education, 93(6), 1026-1049.

Jespersen, N. D., Brady, J. E., \& Hyslop, A. (2011). Chemistry: The molecular nature of matter. Wiley global education.

Kean, E., \& Middlecamp, C. (1985). Panduan belajar kimia dasar. Jakarta: Gramedia.

Layly, L. F. N. (2016). . Identifikasi miskonsepsi siswa kelas X SMA Negeri di Kota Kediri pada materi ikatan kovalen menggunakan tes diagnostik pilihan ganda dua tingkat. Skripsi jurusan kimia-fakultas MIPA $U M$.

Luxford, C. J., \& Bretz, S. L. (2014). Development of the bonding representations inventory to identify student misconceptions about covalent and ionic bonding representations. Journal of chemical education, 91(3), 312-320. 
Nahum, T. L., Hofstein, A., Mamlok-Naaman, R., \& Ziva, B. D. (2004). Can final examinations amplify students'misconceptions in chemistry?. Chemistry education research and practice, 5(3), 301-325.

Nakiboglu, C. (2003). Instructional misconceptions of Turkish prospective chemistry teachers about atomic orbitals and hybridization. Chemistry Education Research and Practice, 4(2), 171-188.

Sendur, G., Toprak, M., \& Pekmez, E. S. (2010, November). Analyzing of students' misconceptions about chemical equilibrium. In international conference on new trends in education and their implications (pp. 1-7).

Setiawan, D., Cahyono, E., \& Kurniawan, C. (2017). Identifikasi dan analisis miskonsepsi pada materi ikatan Kimia menggunakan instrumen tes diagnostik three-tier. Journal of innovative science education, 6(2), 197-204.

Sunyono, S., Wirya, I. W., \& Sujadi, G. (2009). Identifikasi masalah kesulitan dalam pembelajaran kimia SMA kelas X di propinsi Lampung. Jurnal pendidikan MIPA, 10(2), 9-18.

Tan, D. K. C., \& Treagust, D. F. (1999). Evaluating students' understanding of chemical bonding. School science review, 81(294), 75-84.

Uce, M. (2015). Constructing models in teaching of chemical bonds: Ionic bond, covalent bond, double and triple bonds, hydrogen bond and molecular geometry. Educational research and reviews, 10(4), 491500.

Wang, C. Y. (2007). The role of mental-modeling ability, content knowledge, and mental models in general chemistry students' understanding about molecular polarity (Doctoral dissertation, University of Missouri--Columbia). 